This is an Open Access article licensed under the terms of the Creative Commons AttributionNonCommercial-NoDerivs 3.0 License (www.karger.com/OA-license), applicable to the online version of the article only. Distribution for non-commercial purposes only.

In the article by Alshahrani S. and Di Fulvio M., entitled "Expression of the Slc12a1 gene in pancreatic $\beta$-cells: molecular characterization and in silico analysis" [Cell Physiol Biochem 2012;30(1):95-112 (DOI: 10.1159/000339050)], the name of Dr. Francisco J. AlvarezLeefmans was omitted in the submitted manuscript. His name should be included as second author of the paper.

The changes made are as follows:

Authors: Saeed Alshahrani, Francisco J. Alvarez-Leefmans and Mauricio Di Fulvio

Affiliations: Department of Pharmacology and Toxicology, Wright State University, Boonshoft School of Medicine, Dayton, $\mathrm{OH}$

\title{
Acknowledgements section:
}

We are grateful to Drs. Peter Lauf and Norma Adragna for helpful insights and comments. SA is a Student of the Master's of Science Program of the Department of Pharmacology and Toxicology at WSU-BSoM. This work has been supported by the American Diabetes Association (Grant 1-10-JF-14 to MDiF). FJA-L was supported by Wright State University Boonshoft School of Medicine Research Challenge and Seed Grant Programs. 